\title{
From mimetic punctiliousness to imaginative free play
}

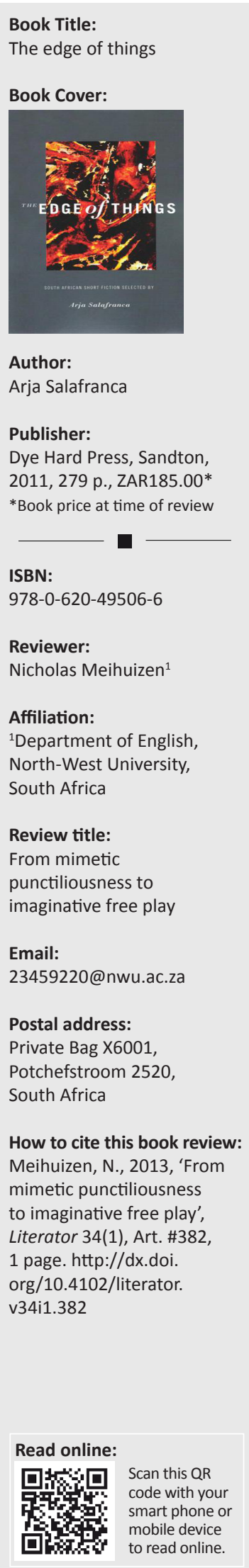

In 1958 Randall Jarrell, the American poet, edited and brought out a collection of stories, Randall Jarrell's Book of Stories, which contains a famous introduction. The book was long out of print but has been recently republished as a New York Review Books Classic (2002). It is, naturally, very difficult to generalise about a book such as the one under review, but there is one section of Jarrell's introduction that seems pertinent to The edge of things, in its mixture of complexity and comprehensiveness:

It is so good, our stories believe, simply to remember: their elementary delight in recognition, familiarity, mimesis, is another aspect of their obsession with all the likenesses of the universe, those metaphors that Proust called essential to style. Stories want to know: everything from the first blaze and breathlessness and fragrance to the last law and structure, but, too, stories don't want to know, don't want to care, just want to do as they please. (Jarrell 2002: $\mathrm{x}$ )

The range of the story: from mimetic punctiliousness to imaginative free play. Arja Salafranca's task, as compiler of The edge of things, is not to ponder the nature of short fiction; it is to present as many works as possible, with an eye on quality, in order to promote the genre in this country. She notes that the stories submitted for publication in the book showed 'an astonishing variety of narratives and approaches, shifting from realism to playful absurdity and crossing the boundaries from the strictly fictional to something that sits just beyond fiction, but isn't quite nonfiction either' (p. 7). Jarrell would have approved.

Looking at the stories themselves one finds it hard to pick out those that deserve special mention, but let me refer to some. 'Bounce' (p. 9), by Jayne Bauling, is a curiously gripping account (perhaps because this reviewer has tried to do the same) of the attempted rescue of a baby lourie, psychologically bound to the loss of a murdered partner. Salafranca's own 'The Iron Lung' (p. 18), juxtaposes two first-person accounts, those of mother and daughter, about life with the iron lung device; the device assumes a figurative significance. Cunningly different from other stories is Liesl Jobson's 'You pay for the view: twenty tips for super pics' (p. 30), a life story constructed around the said tips and moments captured as camera events. The events begin with '1. Hold it steady', and end with '20. Watch the light', and cover a period, not always in strictly chronological order, of 32 years. In this and other stories failed marriages are at issue. I think of Gillian Schutte's 'Doubt' (p. 50), with its erotic daydreams, and Karina Magdalena Szczurek's 'The Basket' (p. 62), where the death of a newly-retired husband in a motorbike accident actually brings the protagonist (and the reader) a sense of relief. In the collection's eponymous 'The edge of things' (p. 78), by Jenna Mervis, the protagonist is alone with her dog in a cottage on the edge of suburban space, that appears to be spied on by possible intruders. She is without, or is separated from, a partner, and the narrator uses this absence and her sense of vulnerability to create suspense. In the end, though, Samson the dog, in the middle of a moonlit night, leads her outdoors, away from her locks and alarms, into a magical dream dimension, 'on the edge of things' in a different sense from that originally suggested. Pravasan Pillay's 'Mr Essop' (p. 137 ) is a matter-of-fact, Hemingwayesque account of an instance of coldly administered cruelty to a child, with some fine moments of dialogue in Chatsworth dialect. Again, it is obviously impossible to mention all the stories in the book, but let me conclude with a brief look at Dan Wylie's 'Solitude' (p. 256). Here we find a punctiliously crafted story, indeed. The protagonist is an aloof, cynical academic, complacently single, with a distaste for the life around him. He works on a crossword puzzle, clue by clue. The puzzle proves intrinsic to the plot, as the life around him, with its grubbiness and despair, enters into his puzzle (though he remains imperturbable).

The book will appeal to lovers of fiction and narrative in whatever forms. Those who relish detail, those who desire free play, are catered for. Not all the stories are of the same quality, but each, in its way, is enjoyable, and is reflective of the old cliché that everyone carries a story, or stories, within him or her. There is something of this democracy of the narrative urge in these stories, which makes of them a useful and enlightening panorama of local experience, states of mind, and states of emotion.

\section{References}

Jarrell, R. (ed.), [1958] 2002, Randall Jarrell's book of short stories, New York Review Book, New York. 